\title{
Streptomyces artemisiae sp. nov., isolated from surface-sterilized tissue of Artemisia annua L.
}

\author{
Guo-Zhen Zhao, Jie Li, Sheng Qin, Hai-Yu Huang, Wen-Yong Zhu, \\ Li-Hua Xu and Wen-Jun Li
}

Correspondence

Wen-Jun Li

wjli@ynu.edu.cn or

liact@hotmail.com

\begin{abstract}
The Key Laboratory for Microbial Resources of the Ministry of Education, PR China, and Laboratory for Conservation and Utilization of Bio-resources, Yunnan Institute of Microbiology, Yunnan University, Kunming, Yunnan 650091, PR China
\end{abstract}

The taxonomic position of an actinomycete strain YIM $63135^{\top}$, which was isolated from the surface-sterilized tissue of Artemisia annua L. collected from Yunnan province, south-west China, was determined by using a polyphasic approach. Morphological and chemical characteristics of the novel strain were consistent with those of the genus Streptomyces. It developed a pinkish aerial mycelium and pinkish-brown substrate mycelium on oatmeal agar. The cell wall of the strain contained LL-diaminopimelic acid. The menaquinones comprised MK-9( $\left.\mathrm{H}_{6}\right)(62.8 \%), \mathrm{MK}-9\left(\mathrm{H}_{8}\right)$ (31.4\%) and MK-9 $\left(\mathrm{H}_{4}\right)$ (5.9\%). The phospholipids were diphosphatidylglycerol,

phosphatidylglycerol, phosphatidylinositol, phosphatidylethanolamine, an unknown glucosaminecontaining phospholipid (GluNu), phosphatidylinositol mannosides and four unknown ninhydrinnegative phospholipids. The major fatty acids were iso- $\mathrm{C}_{16: 0}(30.0 \%)$, anteiso- $\mathrm{C}_{17: 0}(27.3 \%)$ and anteiso- $\mathrm{C}_{15: 0}(17.0 \%)$. The DNA G +C content of strain YIM $63135^{\top}$ was $72.6 \mathrm{~mol} \%$. Phylogenetic analysis of $16 \mathrm{~S}$ rRNA gene sequences revealed that strain YIM $63135^{\top}$ is a member of the genus Streptomyces and exhibited $99.9 \%$ gene sequence similarity to Streptomyces armeniacus NBRC $12555^{\top}$, while low sequence similarity values (<97.0\%) distinguished strain YIM $63135^{\top}$ from all other Streptomyces species. DNA-DNA hybridization studies suggested that strain YIM $63135^{\top}$ represents a different genomic species. On the basis of phenotypic and phylogenetic characteristics, strain YIM $63135^{\top}$ was considered to represent a novel species of the genus Streptomyces, for which the name Streptomyces artemisiae sp. nov. is proposed, with YIM $63135^{\top}\left(=\right.$ CCTCC AA $208059^{\top}=$ DSM $\left.41953^{\top}\right)$ as the type strain.
The genus Streptomyces was initially introduced by Waksman \& Henrici (1943) to encompass aerobic, sporeforming actinomycetes. Streptomyces species have distinct features, such as Gram-positive cell walls, production of extensively branched substrate and aerial mycelia, high DNA G $+\mathrm{C}$ contents and the presence of LL-diaminopimelic acid and absence of characteristic sugars in the cell wall (Locci, 1989; Anderson \& Wellington, 2001). At the time of writing, the genus Streptomyces encompasses nearly 600 species and subspecies with validly published names. Streptomyces species are abundant in soil and are well

\footnotetext{
Abbreviations: DPG, Diphosphatidylglycerol; GluNu, unknown glucosamine-containing phospholipid; $\mathrm{PE}$, phosphatidylethanolamine; $\mathrm{PG}$, phosphatidylglycerol; PI, phosphatidylinositol; PIM, phosphatidylinositol mannosides.

The GenBank/EMBL/DDBJ accession number for the 16S rRNA gene sequence of strain YIM 63135' is EU200685.

A supplementary table comparing fatty acid profiles of strain YIM $63135^{\top}$ and S. armeniacus NBRC $12555^{\top}$ is available with the online version of this paper.
}

known for their ability to produce biologically active secondary metabolites. Streptomycetes are used extensively in industry because of their ability to generate a number of chemical compounds, including antibiotics, enzymes, enzyme inhibitors, antitumour agents and antifungal compounds (Chun et al., 1997; Kim \& Hwang, 2003). In this study, strain YIM $63135^{\mathrm{T}}$ was isolated from surfacesterilized tissue of Artemisia annua L., which was collected from Yunnan province, south-west China. Our polyphasic taxonomic analysis demonstrated that this isolate represents a novel species of the genus Streptomyces.

Plant samples were thoroughly washed in running water to remove all soil and sterilized by an established procedure (Coombs \& Franco, 2003). After being surface-sterilized, the plant samples were sliced and plated on $\mathrm{HV}$ agar (Hayakawa \& Nonomura, 1987) plates supplemented with cycloheximide $\left(50 \mathrm{mg} \mathrm{l}^{-1}\right)$ to suppress fungal growth. Plates were incubated at $28{ }^{\circ} \mathrm{C}$ until the outgrowth of endophytic bacteria was discerned. Colonies originating from plant segments were picked up and pure cultures were obtained by repeated streaking on plates containing TWYE 
medium ( $0.25 \mathrm{~g}$ yeast extract, $0.5 \mathrm{~g} \mathrm{~K}_{2} \mathrm{HPO}_{4}$ and $18 \mathrm{~g}$ agar per litre tap water, $\mathrm{pH}$ 7.2). The purified strain YIM $63135^{\mathrm{T}}$ was picked and maintained on tryptic soy agar slants at $4{ }^{\circ} \mathrm{C}$ and as $20 \%(\mathrm{w} / \mathrm{v})$ glycerol suspensions at $-20{ }^{\circ} \mathrm{C}$.

The morphological characteristics of strain YIM $63135^{\mathrm{T}}$, including spore-chain morphology, spore size and surface ornamentation, were assessed by light and scanning electron microscopy (Philips XL30; ESEM-TMP) of 14-day-old cultures on YIM 38 medium [5 g malt extract, $4 \mathrm{~g}$ yeast extract, $4 \mathrm{~g}$ glucose, vitamin mixture $(0.5 \mathrm{mg}$ each of thiamine-hydrochloride, riboflavin, niacin, pyridoxinehydrochloride, inositol, calcium pantothenate and $p$ aminobenzoic acid and $0.25 \mathrm{mg}$ biotin), $20 \mathrm{~g}$ agar; $\mathrm{pH}$ 7.2]. Aerial spore-mass colour, substrate mycelium pigmentation and coloration of the diffusible pigments of strain YIM $63135^{\mathrm{T}}$ were recorded on ISP (International Streptomyces Project) media (Shirling \& Gottlieb, 1966), Czapek's agar and nutrient agar prepared as described by Dong \& Cai (2001). Colours were determined by using colour chips from the ISCC-NBS colour charts (standard samples, no. 2106) (Kelly, 1964).

Strain YIM $63135^{\mathrm{T}}$ formed an extensively branched substrate mycelium, and aerial hyphae that carried smooth-surfaced spores in spiral spore chains (Fig. 1). The strain is characterized by long spore chains each containing more than 10 spores. Spores were elliptical and around $1.0 \mu \mathrm{m}$ long. Strain YIM $63135^{\mathrm{T}}$ was observed to grow well on a variety of ISP agar media, including yeast extract-malt extract agar (ISP 2), oatmeal agar (ISP 3), inorganic salts starch agar (ISP 4) and glycerol asparagine agar (ISP 5), Czapek's agar, potato extract agar and nutrient agar. Cultural characteristics of strain YIM $63135^{\mathrm{T}}$ are shown in Table 1 . The aerial mycelium with spores was abundant, well-developed and varied from white to pink on different test media. The substrate mycelium was white to pink and orange-brown. Soluble pigments were produced only on ISP 2 agar (pink) and ISP 3 agar (red).

Carbon source utilization was determined according to the methods of Shirling \& Gottlieb (1966) and Locci (1989). Acid production from carbohydrates was assessed as described by Gordon et al. (1974). Growth at various temperatures, $\mathrm{pH}$ and $\mathrm{NaCl}$ concentrations was examined according to $\mathrm{Xu}$ et al. (2005) using tryptic soy broth (TSB) medium as the basal medium. Oxidase activity was determined from the oxidation of tetramethyl-p-phenylenediamine. Catalase activity was determined with $3 \%$ $\mathrm{H}_{2} \mathrm{O}_{2}$ according to standard methods. Other phenotypic characteristics were tested using standard procedures (Goodfellow, 1971; Williams et al., 1983). The physiological and biochemical characteristics of strain YIM $63135^{\mathrm{T}}$ are given in Table 2 and in the species description.

For chemical analysis, biomass from strain YIM $63135^{\mathrm{T}}$ was prepared by culturing in TSB for 7 days at $28{ }^{\circ} \mathrm{C}$ in a rotary shaker (200 r.p.m.), harvesting cells by centrifugation and washing with sterilized water. Isomers of diaminopimelic acid and sugars of whole-cell hydrolysates were analysed
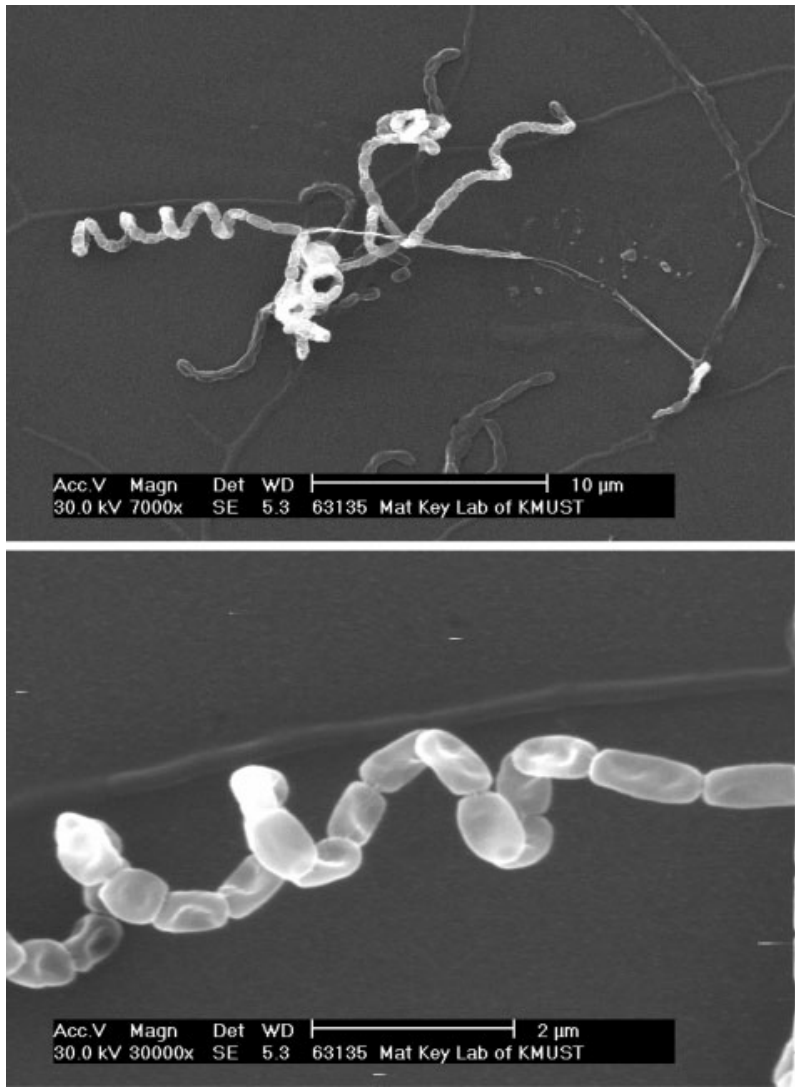

Fig. 1. Scanning electron micrographs showing spiral spore chains and smooth spores of strain YIM $63135^{\top}$ after growth on YIM 38 medium at $28{ }^{\circ} \mathrm{C}$ for 14 days. Bars, $10 \mu \mathrm{m}$ top, $2 \mu \mathrm{m}$ bottom.

according to the procedures developed by Hasegawa et al. (1983) and Lechevalier \& Lechevalier (1970). Phospholipids were examined and identified using the method of Minnikin et al. (1979). Menaquinones were extracted and purified following Collins et al. (1977) and then analysed by HPLC (Tamaoka et al., 1983). Cellular fatty acid analysis was performed using the Sherlock Microbial Identification System (MIDI), according to the manufacturer's instructions. The $\mathrm{G}+\mathrm{C}$ content of genomic DNA was determined by the HPLC method according to Mesbah et al. (1989), with Escherichia coli JM-109 as a control.

Strain YIM $63135^{\mathrm{T}}$ contained LL-diaminopimelic acid as the major diamino acid. Whole-cell hydrolysates contained glucose, galactose, ribose and mannose. The menaquinones were MK-9 $\left(\mathrm{H}_{6}\right)(62.8 \%)$, MK-9 $\left(\mathrm{H}_{8}\right)(31.4 \%)$ and MK$9\left(\mathrm{H}_{4}\right)(5.9 \%)$ and the phospholipids were diphosphatidylglycerol (DPG), phosphatidylglycerol (PG), phosphatidylinositol (PI), phosphatidylethanolamine (PE), an unknown glucosamine-containing phospholipid (GluNu), phosphatidylinositol mannosides (PIM) and four unknown ninhydrin-negative phospholipids. The major fatty acids of strain YIM $63135^{\mathrm{T}}$ were iso- $\mathrm{C}_{16: 0}(30.0 \%)$, 
Table 1. Cultural characteristics of strain YIM $63135^{\top}$

Colours are according to Kelly (1964).

\begin{tabular}{|lccc|}
\hline \multirow{2}{*}{ Agar medium } & \multicolumn{2}{c}{ Colour of mycelium } & \multirow{2}{*}{ Soluble pigment } \\
\cline { 2 - 3 } & Spore mass & Substrate & \\
\hline Czapek's & Pink & White & Absent \\
Potato extract & Yellow-white & Pink & Absent \\
Nutrient & White & Yellow-white & Absent \\
Yeast extract-malt extract (ISP 2) & White & Yellow-white & Pink \\
Oatmeal (ISP 3) & Pink & Pink-brown & Red \\
Inorganic salts starch (ISP 4) & White & Yellow-white & Absent \\
Glycerol asparagine (ISP 5) & White & Yellow-white & Absent \\
\hline
\end{tabular}

anteiso- $\mathrm{C}_{17: 0}(27.3 \%)$ and anteiso- $\mathrm{C}_{15: 0}(17.0 \%)$; this profile was very similar to that of the type strain of Streptomyces armeniacus (Supplementary Table S1). The DNA G + C content of strain YIM $63135^{\mathrm{T}}$ was $72.6 \mathrm{~mol} \%$. All morphological and chemical features of strain YIM $63135^{\mathrm{T}}$ were consistent with its assignment to the genus Streptomyces (Williams et al., 1989; Manfio et al., 1995).
Extraction of genomic DNA, PCR amplification and sequencing of the $16 \mathrm{~S}$ rRNA gene were performed as described by Li et al. (2007). Multiple alignments with corresponding sequences of representatives of the genus Streptomyces (retrieved from the GenBank/EMBL/DDBJ database) and calculations of levels of sequence similarity were carried out using CLUSTAL_X (Thompson et al., 1997).

Table 2. Phenotypic properties of strains $\mathrm{YIM} 63135^{\top}$ and $S$. armeniacus NBRC $12555^{\top}$

Data from this study under identical growth conditions.

\begin{tabular}{|c|c|c|}
\hline Characteristic & YIM $63135^{\mathrm{T}}$ & S. armeniacus NBRC $12555^{\mathrm{T}}$ \\
\hline Urea hydrolysis & - & + \\
\hline \multicolumn{3}{|l|}{ Utilization as sole carbon sources } \\
\hline Dulcitol & + & - \\
\hline Erythritol & - & + \\
\hline Aesculin & - & + \\
\hline D-Galactose & + & - \\
\hline Glucose & + & - \\
\hline Glycerol & + & - \\
\hline Inositol & - & + \\
\hline Maltose & - & + \\
\hline D-Mannose & + & - \\
\hline L-Rhamnose & + & - \\
\hline D-Sorbitol & + & - \\
\hline \multicolumn{3}{|l|}{ Utilization as sole nitrogen sources } \\
\hline Adenine & - & + \\
\hline L-Asparagine & + & - \\
\hline L-Phenylalanine & + & - \\
\hline L-Serine & + & - \\
\hline L-Tyrosine & + & - \\
\hline Acid production from $\mathrm{D}$-xylose & + & - \\
\hline \multicolumn{3}{|l|}{ Growth at: } \\
\hline $4{ }^{\circ} \mathrm{C}$ & - & + \\
\hline $45{ }^{\circ} \mathrm{C}$ & + & - \\
\hline pH 5.0 & + & - \\
\hline $\mathrm{pH} 9.0$ & + & - \\
\hline $7 \% \mathrm{NaCl}$ & - & + \\
\hline Menaquinones & MK-9 $\left(\mathrm{H}_{4}\right)$, MK-9(H $\left.\mathrm{H}_{6}\right)$, MK-9 $\left(\mathrm{H}_{8}\right)$ & MK-9 $\left(\mathrm{H}_{4}\right)$, MK-9 $\left(\mathrm{H}_{6}\right)$ \\
\hline
\end{tabular}


A phylogenetic tree was reconstructed using the neighbourjoining method of Saitou \& Nei (1987) from $K_{\text {nuc }}$ values (Kimura, 1980) by using MEGA version 4.0 (Tamura et al., 2007). The topology of the phylogenetic tree was evaluated by using the bootstrap resampling method of Felsenstein (1985) with 1000 replicates.

The almost-complete 16S rRNA gene sequence (1419 bp) for strain YIM $63135^{\mathrm{T}}$ was obtained. Phylogenetic analysis based on 16S rRNA gene sequences indicated that the organism is phylogenetically related to members of the genus Streptomyces, with Streptomyces armeniacus NBRC $12555^{\mathrm{T}}$ as the closest related type strain (99.9\%) (Fig. 2). All other representatives of the genus Streptomyces exhibited lower sequence similarity to strain YIM $63135^{\mathrm{T}}$ $(<97.0 \%)$. In view of the high level of $16 \mathrm{~S}$ rRNA gene sequence similarity between isolate YIM $63135^{\mathrm{T}}$ and $S$. armeniacus NBRC $12555^{\mathrm{T}}$, DNA-DNA relatedness between them was studied according to the fluorometric microwell method (Ezaki et al., 1989; Christensen et al., 2000; He et al., 2005). Fluorescence intensities were measured using a fluorescence microplate reader (Spectra Max Gemini xps). Hybridizations were performed with six replications. The DNA-DNA hybridization rate was calculated following the method of $\mathrm{He}$ et al. (2005). The DNA-DNA relatedness between strain YIM $63135^{\mathrm{T}}$ and S. armeniacus NBRC $12555^{\mathrm{T}}$ was $41.3 \%$, which is well below the $70 \%$ cut-off point for recognition of genomic species (Stackebrandt \& Goebel, 1994), suggesting that strain YIM $63135^{\mathrm{T}}$ should be considered to represent a different genomic species of the genus Streptomyces.

Besides the genotypic evidence, strain YIM $63135^{\mathrm{T}}$ can also be distinguished from its closest relative by additional phenotypic characteristics. According to results obtained in this study, there are many phenotypic differences between strain YIM $63135^{\mathrm{T}}$ and S. armeniacus NBRC $12555^{\mathrm{T}}$, including differences in utilization of sole carbon and nitrogen sources, degradation activity, temperature and $\mathrm{pH}$ for growth, tolerance of $\mathrm{NaCl}$ and menaquinone profiles (Table 2).

Strain YIM $63135^{\mathrm{T}}$ did not hydrolyse urea. It utilized dulcitol, D-galactose, glucose, glycerol, D-mannose, Lrhamnose, D-sorbitol, L-asparagine, L-phenylalanine, Lserine and L-tyrosine, but none of these were used by S. armeniacus NBRC $12555^{\mathrm{T}}$. In contrast, S. armeniacus NBRC $12555^{\mathrm{T}}$ utilized erythritol, aesculin, inositol, maltose and adenine. Strain YIM $63135^{\mathrm{T}}$ could grow at $45{ }^{\circ} \mathrm{C}$ and pH 5.0 and 9.0, but $S$. armeniacus NBRC $12555^{\mathrm{T}}$ could not grow under these culture conditions. S. armeniacus NBRC $12555^{\mathrm{T}}$ tolerated up to $7 \% \mathrm{NaCl}$, while this ability was not shown by strain YIM $63135^{\mathrm{T}}$. MK- $9\left(\mathrm{H}_{8}\right)$ was present in the menaquinone profile of strain YIM $63135^{\mathrm{T}}$, whereas it was absent from S. armeniacus NBRC $12555^{\mathrm{T}}$. Based on this genotypic and phenotypic evidence, strain YIM $63135^{\mathrm{T}}$ warrants classification as the type strain of a novel species of the genus Streptomyces, for which the name Streptomyces artemisiae sp. nov. is proposed.

\section{Description of Streptomyces artemisiae sp. nov.}

Streptomyces artemisiae (ar.te.mi'si.ae. L. n. artemisia mugwort, and also a plant genus; L. gen. n. artemisiae of Artemisia, referring to isolation of the type strain from Artemisia annua L.).

Aerobic, Gram-stain-positive actinomycete that forms an extensively branched substrate mycelium and an aerial mycelium that differentiates into spiral spore chains. Spores are elliptical or short rods, and the spore surface is smooth. Aerial mycelium is white to pink, substrate mycelium is white to pink and orange-brown. Soluble pigments are produced on ISP 2 agar (pink) and on ISP 3 agar (red). Additional cultural characteristics on various agar media are given in Table 1 . Growth occurs at $10-45{ }^{\circ} \mathrm{C}$

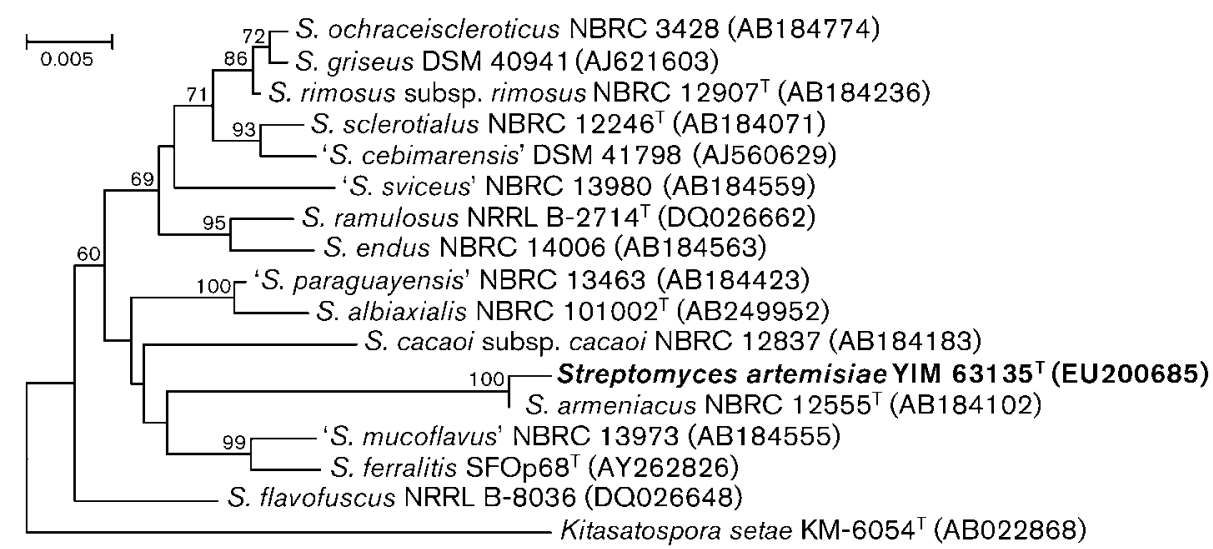

Fig. 2. Neighbour-joining phylogenetic dendrogram based on $16 \mathrm{~S}$ rRNA gene sequences showing relationships between strain YIM $63135^{\top}$ and related taxa. The sequence of Kitasatospora setae KM-6054 ${ }^{\top}$ (AB022868) was used as an outgroup. Numbers represent confidence levels from 1000 replicate bootstrap samplings as percentages; values $>50 \%$ are shown at branch points. Bar, 0.005 substitutions per nucleotide position. 
and $\mathrm{pH}$ 5.0-9.0. Optimal growth at $28{ }^{\circ} \mathrm{C}$ and $\mathrm{pH}$ 7.0-8.0. Tolerates $\mathrm{NaCl}$ up to $5 \%$. Catalase is produced. Negative for Voges-Proskauer and methyl red tests, oxidase reaction, production of $\mathrm{H}_{2} \mathrm{~S}$, nitrate reduction and milk coagulation and peptonization. Starch and Tweens 20, 40 and 80 are hydrolysed, but cellulose, gelatin and urea are not hydrolysed. Utilizes dulcitol, D-galactose, glucose, glycerol, D-mannose, raffinose, L-rhamnose and D-sorbitol as sole carbon sources. Erythritol, aesculin, inositol, maltose, sodium acetate and sucrose are not utilized. LAlanine, L-arginine, L-asparagine, glycine, hydroxy-L-proline, hypoxanthine, L-lysine, L-phenylalanine, L-serine, Ltyrosine, L-valine and xanthine, but not adenine, can be used as sole nitrogen sources. Acid is produced from Darabinose, L-arabinose, cellobiose, fructose, D-fucose, lactose, mannitol, ribose, starch, trehalose and D-xylose. The diagnostic amino acid in the peptidoglycan is LLdiaminopimelic acid, and glucose, galactose, ribose and mannose are present in whole-cell hydrolysates (cell wall type I). Phospholipids are DPG, PG, PI, PE and GluNu, with trace amounts of PIM and four unknown phospholipids. The quinone system is composed of the major compounds MK-9 $\left(\mathrm{H}_{6}\right)$ and MK-9 $\left(\mathrm{H}_{8}\right)$ and minor amounts of MK-9 $\left(\mathrm{H}_{4}\right)$. The major cellular fatty acids are iso- $\mathrm{C}_{16: 0}$, anteiso- $\mathrm{C}_{17: 0}$ and anteiso- $\mathrm{C}_{15: 0}$. The $\mathrm{G}+\mathrm{C}$ content of genomic DNA from the type strain is $72.6 \mathrm{~mol} \%$.

The type strain is YIM $63135^{\mathrm{T}}$ (=CCTCC AA $208059^{\mathrm{T}}$ $=$ DSM $41953^{\mathrm{T}}$ ), isolated from surface-sterilized tissue of Artemisia annua L. collected in Yunnan Province, southwest China.

\section{Acknowledgements}

We are grateful to $\mathrm{Mr} \mathrm{Yu}$-Guang Zhou for providing the reference strain of Streptomyces armeniacus. This research was supported by the National Basic Research Program of China (no. 2010CB833800) and the Ministry of Science and Technology, PR China (2006DFA33550) and Yunnan Provincial Natural Science Foundation (no. 2009DA002).

\section{References}

Anderson, A. S. \& Wellington, E. M. H. (2001). The taxonomy of Streptomyces and related genera. Int J Syst Evol Microbiol 51, 797-814.

Christensen, H., Angen, O., Mutters, R., Olsen, J. E. \& Bisgaard, M. (2000). DNA-DNA hybridization determined in micro-wells using covalent attachment of DNA. Int J Syst Evol Microbiol 50, 1095-1102.

Chun, J. S., Youn, H. D., Yim, Y. I., Lee, H. K., Kim, M. Y., Hah, Y. C. \& Kang, S. O. (1997). Streptomyces seoulensis sp. nov. Int J Syst Bacteriol 47, 492-498.

Collins, M. D., Pirouz, T., Goodfellow, M. \& Minnikin, D. E. (1977). Distribution of menaquinones in actinomycetes and corynebacteria. J Gen Microbiol 100, 221-230.

Coombs, J. T. \& Franco, C. M. M. (2003). Isolation and identification of actinobacteria from surface-sterilized wheat roots. Appl Environ Microbiol 69, 5603-5608.

Dong, X.-Z. \& Cai, M.-Y. (editors) (2001). Determination of biochemical properties. In Manual for the Systematic Identification of General Bacteria, pp. 370-398. Beijing: Science Press (in Chinese).
Ezaki, T., Hashimoto, Y. \& Yabuuchi, E. (1989). Fluorometric deoxyribonucleic acid-deoxyribonucleic acid hybridization in microdilution wells as an alternative to membrane filter hybridization in which radioisotopes are used to determine genetic relatedness among bacterial strains. Int J Syst Bacteriol 39, 224-229.

Felsenstein, J. (1985). Confidence limits on phylogenies: an approach using the bootstrap. Evolution 39, 783-791.

Goodfellow, M. (1971). Numerical taxonomy of some nocardioform bacteria. J Gen Microbiol 69, 33-80.

Gordon, R. E., Barnett, D. A., Handerhan, J. E. \& Pang, C. H.-N. (1974). Nocardia coeliaca, Nocardia autotrophica, and the nocardin strain. Int J Syst Bacteriol 24, 54-63.

Hasegawa, T., Takizawa, M. \& Tanida, S. (1983). A rapid analysis for chemical grouping of aerobic actinomycetes. J Gen Appl Microbiol 29, 319-322.

Hayakawa, M. \& Nonomura, H. (1987). Humic acid-vitamin agar, a new medium for selective isolation of soil actinomycetes. J Ferment Technol 65, 501-509.

He, L., Li, W., Huang, Y., Wang, L. M., Liu, Z. H., Lanoot, B. J., Vancanneyt, M. \& Swings, J. (2005). Streptomyces jietaisiensis sp. nov., isolated from soil in northern China. Int J Syst Evol Microbiol 55, 1939-1944.

Kelly, K. L. (1964). Inter-Society Color Council - National Bureau of Standards Color Name Charts Illustrated with Centroid Colors. Washington, DC: US Government Printing Office.

Kim, B. S. \& Hwang, B. K. (2003). Biofungicides. In Fungal Biotechnology in Agricultural, Food and Environmental Applications, pp. 123-133. Edited by D. K. Arora. New York: Marcel Dekker.

Kimura, M. (1980). A simple method for estimating evolutionary rates of base substitutions through comparative studies of nucleotide sequences. J Mol Evol 16, 111-120.

Lechevalier, M. P. \& Lechevalier, H. A. (1970). Chemical composition as a criterion in the classification of aerobic actinomycetes. Int J Syst Bacteriol 20, 435-443.

Li, W. J., Xu, P., Schumann, P., Zhang, Y. Q., Pukall, R., Xu, L. H., Stackebrandt, E. \& Jiang, C. L. (2007). Georgenia ruanii sp. nov., a novel actinobacterium isolated from forest soil in Yunnan (China) and emended description of the genus Georgenia. Int J Syst Evol Microbiol 57, 1424-1428.

Locci, R. (1989). Streptomyces and related genera. In Bergey's Manual of Systematic Bacteriology, vol. 4, pp. 2451-2508. Edited by S. T. Williams, M. E. Sharpe \& J. G. Holt. Baltimore: Williams \& Wilkins.

Manfio, G. P., Zakrzewska-Czerwinska, J., Atalan, E. \& Goodfellow, M. (1995). Towards minimal standards for the description of Streptomyces species. Biotechnologia 7-8, 242-253.

Mesbah, M., Premachandran, U. \& Whitman, W. B. (1989). Precise measurement of the $\mathrm{G}+\mathrm{C}$ content of deoxyribonucleic acid by high-performance liquid chromatography. Int J Syst Bacteriol 39, 159-167.

Minnikin, D. E., Collins, M. D. \& Goodfellow, M. (1979). Fatty acid and polar lipid composition in the classification of Cellulomonas, Oerskovia and related taxa. J Appl Bacteriol 47, 87-95.

Saitou, N. \& Nei, M. (1987). The neighbor-joining method: a new method for reconstructing phylogenetic trees. Mol Biol Evol 4, $406-425$.

Shirling, E. B. \& Gottlieb, D. (1966). Methods for characterization of Streptomyces species. Int J Syst Bacteriol 16, 313-340.

Stackebrandt, E. \& Goebel, B. M. (1994). Taxonomic note: a place for DNA-DNA reassociation and $16 \mathrm{~S}$ rRNA sequence analysis in the present species definition in bacteriology. Int J Syst Bacteriol 44, 846-849. 
Tamaoka, J., Katayama-Fujimura, Y. \& Kuraishi, H. (1983). Analysis of bacterial menaquinone mixtures by high performance liquid chromatography. J Appl Bacteriol 54, 31-36.

Tamura, K., Dudley, J., Nei, M. \& Kumar, S. (2007). MEGA4: molecular evolutionary genetics analysis (MEGA) software version 4.0. Mol Biol Evol 24, 1596-1599.

Thompson, J. D., Gibson, T. J., Plewniak, F., Jeanmougin, F. \& Higgins, D. G. (1997). The CLUSTAL_X windows interface: flexible strategies for multiple sequence alignment aided by quality analysis tools. Nucleic Acids Res 25, 4876-4882.

Waksman, S. A. \& Henrici, A. T. (1943). The nomenclature and classification of the actinomycetes. J Bacteriol 46, 337-341.
Williams, S. T., Goodfellow, M., Alderson, G., Wellington, E. M. H., Sneath, P. H. A. \& Sackin, M. J. (1983). Numerical classification of Streptomyces and related genera. J Gen Microbiol 129, 1743-1813.

Williams, S. T., Goodfellow, M. \& Alderson, G. (1989). Genus Streptomyces Waksman and Henrici 1943, 339 ${ }^{\mathrm{AL}}$. In Bergey's Manual of Systematic Bacteriology, vol. 4, pp. 2452-2492. Edited by S. T. Williams, M. E. Sharpe \& J. G. Holt. Baltimore: Williams \& Wilkins.

Xu, P., Li, W. J., Tang, S. K., Zhang, Y. Q., Chen, G. Z., Chen, H. H., Xu, L. H. \& Jiang, C. L. (2005). Naxibacter alkalitolerans gen. nov., sp. nov., a novel member of the family Oxalobacteraceae isolated from China. Int J Syst Evol Microbiol 55, 1149-1153. 